軽金属 第 61 巻 第 10 号 (2011), 544-552

\title{
アルミニウムの微細組織に関する $\mathrm{X}$ 線回折法による 2,3 の研究
}

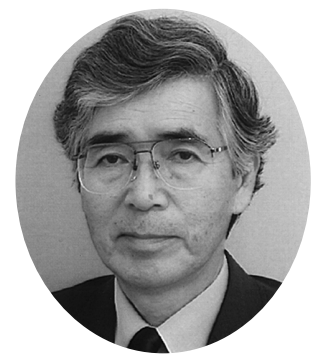

美浦 康宏 $*$

Journal of The Japan Institute of Light Metals, Vol. 61, No. 10 (2011), 544-552

\section{A few works on the microstructure of aluminum by means of $\mathrm{X}$-ray diffraction techniques}

\author{
Yasuhiro MIURA*
}

\begin{abstract}
Keywords: aluminum, X-ray diffraction topography, dislocation source, vacancy supersaturation, dynamic recovery and
\end{abstract} recrystallization, synchrotron Laue method

\section{1.はじめに}

筆者は, 研究を始めた頃から, 純アルミニウム単結晶や純 銅単結晶の転位組織や变形組織にかかわる実験研究を行って きた。種々の X 線回折法（特に Lang 法や Berg-Barrett 法な ぞの X 線回折顕微法) や転位腐食法（エッチピット法）を直 接観察に利用した。後に，合金の転位・变形組織や析出組織 にも対象を広げ，電子顕微鏡法やその他種々の解析・分析法 を併用するようになった。また，新規アルミニウム合金開発 の指針を得るための研究にも着手し，種々の基本合金系 （Al-Li 系合金や Al-Sc 系合金など）について組織解析，組織 形成過程の調査, および変形・強度特性の解明を行った。さ らに，遷移元素添加アルミニウム合金（Al-Cr 合金など）の 超急冷粉末之薄帯の構造・組織解析之熱安定性調査やアルミ 二ウム基金属間化合物（ $\mathrm{L}_{2}$ 型 $\mathrm{Al}_{3} \mathrm{X}$ 化合物）の転位性状解析 之強度・変形特性調查など，新しい高温材として期待された 合金系の研究も行った。一方, 高純度アルミニウム箔の転位 組織とエッチング特性の関係調査など，既存工業材料の機能 改善への指針を得るための研究も行った。

以上，これまでの研究に利用した手法や機器を中心に述べ たが，研究内容はすべて金属組織学に含まれる。

本稿では, X 線回折法を主な実験手段として行った純アルミ ニウム単結晶の転位組織や变形組織に関する研究を話題とし てとりあげる。

まず X 線回折顕微法（Lang 法, Berg-Barrett法）および転 位に関して簡単な説明を行う。つづいて下記いくつかの課題 について，筆者らの研究グループの成果を中心に述べる。

(i) Lang 法による観察に基づく純了ルミニウムバルク単結 晶の転位㧍よび冷却・加熱中の転位の発生・消滅過程の解析

（ii）Berg-Barrett 法による観察に基づく純アルミニウム単 結晶の高温引張変形組織の解析

（iii）放射光ラウエ法その場測定による純アルミニウム単結 晶の高温圧縮変形中の再結晶発現の直接的証明

\section{2. 基礎的事項}

\section{1 X 線回折顕微法 ${ }^{1) ~ 6)}$}

$\mathrm{X}$ 線回折顕微法（X線トポグラフィ, 以後 XT と記す）は 試料結晶内の格子欠陥や格子ひずみの形状や場所的な分布を 回折効果を利用して観察する方法である。X線の回折斑点に は結晶の組織や構造の欠陥が反映されるので, 回折斑点の拡 大像が得られれば転位などの欠陥に関する情報が得られる。 回折効果を利用する点では透過電子顕微鏡法と同じであり, 一方向の回折線を用いる暗視野法に類似する。しかし，X線 は電気的に中性であるため, 便利なレンズ系技術が確立され ておらず，電子顕微鏡の場合のように容易に拡大像を得るこ とができないのが現状である。XT は反射法と透過法に分類 され, さらにX 線源の種類 (単色, 白色), 試料の違い (単 結晶, 多結晶), 抢よび配置などによっていくつかに分かれ, 得られるXT像の解像度も異なる。

図 1 には透過法の Lang 法 ${ }^{8)}$ と反射法である Berg-Barrett 法9,10) の X 線散乱面上の配置を示す 2),4)

現在最屯頻繁に利用されているのは高分解能 XT と言われ るL Lang 法である。微小焦点から出た短波長の特性 X 線 （MoK $\alpha_{1}$ など）による低指数面加らの反射を利用する。試料 をX線源に対して静止した状態では, 試料の三角形領域（図 1 の $\left.\mathrm{ABB}^{\prime}\right)$ からの情報が得られる。これをセクショントポグ ラフ（section topograph）とよんでいる。一方，試料をX線 源に対してスキャンすることによって試料の広い範囲のトポ グラフ（プロジェクショントポグラフ, projection topograph） が得られる。

一方, 反射法である Berg-Barrett 法 ${ }^{9), 10)}$ では個々の転位を 識別することは一般に容易ではないが, 転位セル壁や带結晶 粒界などの比較的大きい欠陥の観察が可能である。線焦点か らの長波長の X 線（FeK $\alpha$ など）を使用する。長波長の X 線 を用いる理由は大きな Bragg 角（数十度）を必要とするから である。しかし, 試料の広範囲にわたって, 数 $\mu \mathrm{m}$ 程度の深

*九州大学名誉教授 (福岡市中央区)。Professor Emeritus, Kyushu University (Fukuoka, Japan). E-mail: f_tobiume@ybb.ne.jp

受付日：平成 23 年 7 月 11 日 受理日：平成 23 年 8 月 2 日 
(A) Lang 法

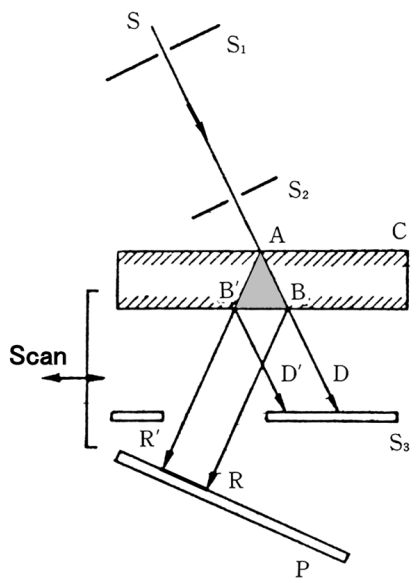

(B) Berg-Barrett 法

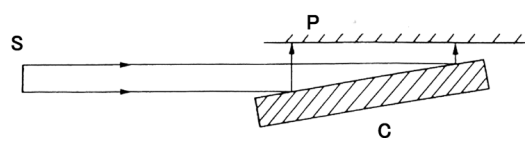

図 1 X 線回折顕微法における配置（A）Lang 法，(B） Berg-Barrett 法, S：X線源, C：結晶, P：乾板

さの像を 1 枚の写真に収めることができるという利点がある。 XT の原理や配置のみならず金属結晶の転位やその他の欠

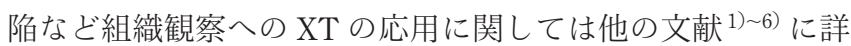
しい。透過電子顕微鏡（TEM）と比較すれば，基本的には， $\mathrm{X}$ 線之電子線の結晶による回折現象の違いに起因して両者の 特徴や違いが生じる。

XTの特徴としては：

（イ）厚い試料を破壊せずにバルク状態で観察することが 可能。X 線の吸収が比較的小さい $\mathrm{Al}$ の場合, 完全度が高け れば厚さ $1 \mathrm{~mm}$ 以上の試料でも使用可能。

（ロ）1枚のXTを撮影した後に, 試料に変形, 熱処理, 照 射などの処置を加えることが比較的容易。種々のその場観察 屯可能。

（ハ）通常の観察条件では, 試料の $X$ 線照射損傷は無視で きる。

（二）個々の転位の識別は比較的良質の単結晶（転位密度 $\left.\rho_{\mathrm{d}} \leqq \sim 10^{3} \mathrm{~cm} / \mathrm{cm}^{3}\right)$ に限られ, 分解能は $1 \mu \mathrm{m}$ 程度にとどまる。

以上の特徴を TEM の特徵と比較すれば，両者が多くの点 で相補的な性格をもつことが理解される。

歴史的にみれば，XT は Berg-Barrett 法 ${ }^{9), 10)}$ や Schultz 法 ${ }^{11)}$ などの反射法にさかのぼる。これらの方法においては像の分 解能むさほよ゙高くなく, 当時は種々の物質において今日ほど 良質の単結晶が得られていなかったので，転位など個々の欠 陥を観察することができず，覀粒界や变形帯などのより巨視 的な構造の観察に重点が置かれていた。現在の高分解能 XT は 1950 年代後半から開発されてきた。Langによって Si 中の 転位がはじめて観察されたのが 1958 年である。その後 $\mathrm{Si}$, Ge，LiFなどの非金属のみならず，金属においても良質結晶 が得られるようになり，XTの技術開発・改良に伴って転位 など個々の欠陷の観察が行われるようになった。しかし，金
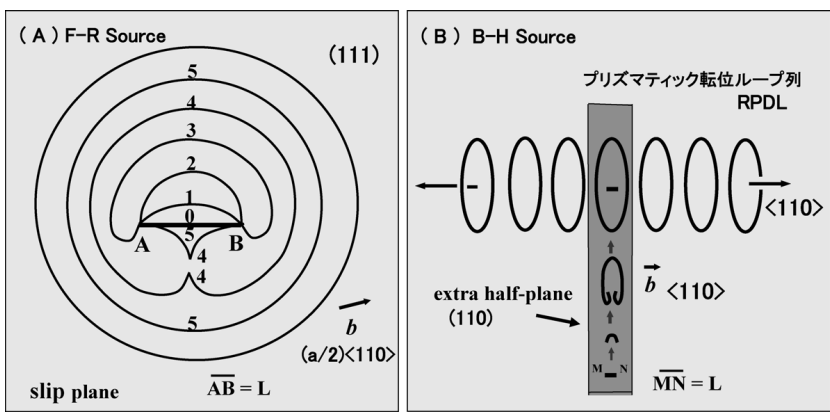

図 2 Frank-Read (F-R) 源（AB）および Bardeen Herring (B-H) 源 (MN)

属結晶への応用例はさほど多くはない。

以下, この節の最後に, XTにおける転位像幅と試料の転 位密度の関係を簡単に述べる。

$\mathrm{X}$ 線回折に拈ける転位像の幅は数 $\mu \mathrm{m}$ 以上であり, 電子線 の場合と比べて 2,3 桁大きい。これはX $\mathrm{X}$ 線の波長が長く反 射の角度広がりが小さいため，ゆるやかに減衰する転位のひ ずみ場 $\left(\propto r^{-1}, r\right.$ : 転位芯からの距離 $)$ を X 線がより遠い地 点まで感じるからである。結果として，転位像幅は広くなる。 本稿で述べる Lang 法による $\mathrm{Al}$ 中の転位像は主として消衰効 果による。その場合, 転位像幅 $(w)$ は, $w=\xi_{g}(g \cdot b) / 2 \pi$, で 表される1),2)。 $\xi_{g}$ : 消衰距離, $\boldsymbol{g}$ : 回折ベクトル, $b$ : バーガー ス・ベクトル。この式による像幅の推定值と実験による観察 值の間にはよい一致が認められている。

トポグラフ上で個々の転位線を識別するためには転位の平 均間隔が転位像幅と同程度以上になるように試料の転位密度 を低下させることが必要である。本稿で述べる実験での転位 像幅は $10 \mu \mathrm{m}$ 程度である。転位密度 $\left(\rho_{\mathrm{d}}\right)$ と転位の平均間隔 $\left(L_{\mathrm{d}}\right)$ の関係を表す式, $L_{\mathrm{d}}=\rho_{\mathrm{d}}{ }^{-1 / 2}$, に従って単純な試算を行 えば，個々の転位を識別するための上限の転位密度は $\rho_{\mathrm{d}}=$ $10^{6} / \mathrm{cm}^{2}$ となる。しかし, 個々の転位の挙動を観察・解析する ためにはさらに低転位密度の結晶による実験が望ましい。

\section{2 転位源, 転位に働く力, 転位の力学的安定形状}

アルミニゥム中の転位は他の金属結晶の転位と同じように 種々の力 (外力 : $f_{\mathrm{e}}$, 線張力 : $f_{\mathrm{L}}$, 熱力学的な力 : $f_{\mathrm{C}}$ ) を受 ける。臨界值以上の外力が働けば Frank-Read 源 ${ }^{12)}$ (F-R 源, 転位増殖源）の活動によって，すべり面上で転位が増殖する (図 $2(\mathrm{~A})$ )。F-R 源が活動するための臨界せん断応力 $\left(\tau_{\mathrm{C}}\right)$ は次式で与えられる。

$$
\tau_{\mathrm{C}}=\mu b / L
$$

ここで $\mu$ : 剛性率, $b$ : バーガース・ベクトル, $L$ : 転位源の 長さである。一方, 点欠陥濃度が過 (未) 飽和状態では刃状 転位が点欠陥の消滅場所（sink）または湧源（source）とし て働く。その結果, 刃状転位に熱力学的な力が働く。この力 は過 (未) 飽和度の対数 $\left(m C / C_{0}\right)$ に比例する $(C$ : 空孔濃 度, $C_{0}$ : 平衡空孔濃度)。Bardeen-Herring 源 ${ }^{13)}$ ( $\mathrm{B}-\mathrm{H}$ 源）の ような Climb Source（刃状成分からなる転位源）に臨界值以 上の熱力学的な力が㗢けば, その活動によってプリズマ ティック転位ループ（純粋な刃状転位からなるループ）が形 成される（図 2 (B))。長さ $L$ の B-H 源が活動するための臨 界空孔濃度を $C_{\mathrm{c}}$ とすれば, $\left(\ln C_{\mathrm{c}} / C_{0}\right)$ は次式で表される ${ }^{16)}$ 。

$$
\ln \left(C_{\mathrm{c}} / C_{0}\right)=\mu b \Omega / L k T
$$


ここで， $\Omega$ : 原子容 $\left(\sim b^{3}\right), k$ : ボルッマン定数, $T$ : 絶対 温度である。また，らせん転位のジョグに点欠陥が吸収され ることによって，つるまきばね状転位が形成され，さらにプ リズマティック転位ループ列へと発展する場合むある。

式（1）および（2）から明らかなように，F-R 源が活動する ための臨界応力は転位源の長さ $(L)$ の逆数に比例 L, B-H 源 の場合は臨界応力は空孔過飽和度 $\left(m C / C_{0}\right)$ に比例し, 長さ $(L)$ 之温度 $(T)$ の逆数に比例する。

転位は熱力学的には非平衡欠陥である。熱平衡欠陥である 原子空孔などの点欠陥とは対照的である。したがって高純度 アルミニウム単結晶の場合でも, 高温・長時間の焼なましに よってほとんど無転位の状態が得られることが期待される。 しかし, 実在の結晶の転位は転位同士，あるいはほかの欠陥 や不純物元素之の相互作用によって種々の準安定状態を形成 し，容易には消失しない。したがって，無転位のバルク結晶 を得ることは非常に難しい。

結晶の加熱や冷却過程に扔いては点欠陥（原子空孔や格子 間原子）の生成・消滅が繰返される。この現象は加熱速度や 冷却速度に依存することはもちろん, 点欠陥の湧源や消滅場 所 (結晶表面, 結晶粒界, 刃状転位, およびその他の欠陥) の状態にも影響される。高温長時間の焼なましによって転位 密度が大幅に低下したとしても, 室温への泠却過程において, 残存転位と点欠陥の相互作用によって多くの転位が生まれる 可能性が高い。

本節の冒頭で述べたように, 転位に働く力は 3 通り考えら れる。外力 $\left(f_{\mathrm{e}}\right)$, 線張力 $\left(f_{\mathrm{L}}\right)$, および熱力学的な力 $\left(f_{\mathrm{C}}\right)$ の 3 者の総和がゼロになるとき, 転位は力学的安定状態にあ るといえる。これは, 転位が直線状, 円形状あるいはつるま きばね状のいずれかの場合のみに限られる14)。したがって, 結晶中の転位は，粒界や他の転位などの欠陥之の相互作用が 無視できるような状況では直線，円形，あるいはつるまきば 㸚の形状になる傾向があると理解される。転位論の詳細に関

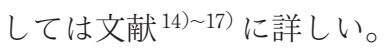

\section{Lang 法による観察に基づく純アルミニウムバル ク単結晶の転位および冷却・加熱中の転位の発 生・消滅過程の解析}

\subsection{X線トポグラフで観察される転位の形状による分類}

十分に焼なましした板状 $\mathrm{Al}$ 単結晶の $\mathrm{X}$ 線トポグラフを図 3 に示す $\left.{ }^{6}, 7\right)$ (試料は $693 \mathrm{~K}$ から室温へ炉中冷却。方位を $\{111\}$

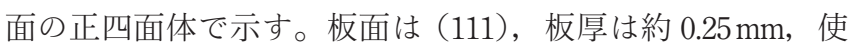
用 X 線は $\mathrm{Mo} K \alpha_{1}$, 回折べクトル $\left.\boldsymbol{g}=\langle 111\rangle\right)$ 。

転位像について特徵的な事柄を挙げると，(i) 転位像の幅 が広く( 数十 $\mu \mathrm{m})$, (ii) 転位密度が低い $\left(\rho_{\mathrm{d}}=10^{3} \mathrm{~cm} / \mathrm{cm}^{3}\right.$ 程 度)ことである。透過電子顕微鏡（TEM）で観察される転位の 像幅が一般に数 $\mathrm{nm}$ 数十 $\mathrm{nm}$ 以下であることと対照的である。

トポグラフで観察される転位を形状によって以下の 3 種類 に分類することができる ${ }^{8)}$ 。

（A）軸が〈110〉に平行なつるまきば状状転位（Helical Dislocation, 図 3 中の A など, 以後 $\mathrm{HD}$ 転位と表記する)

（B）軸が〈110〉に平行な〈110〉同軸プリズマティック転 位ループ列（Row of Prismatic Dislocation Loops，図 3 中の B など，以後 RPDL 転位と表記する)

（C）ランダム形状の転位（Randomly Curved Dislocation，図

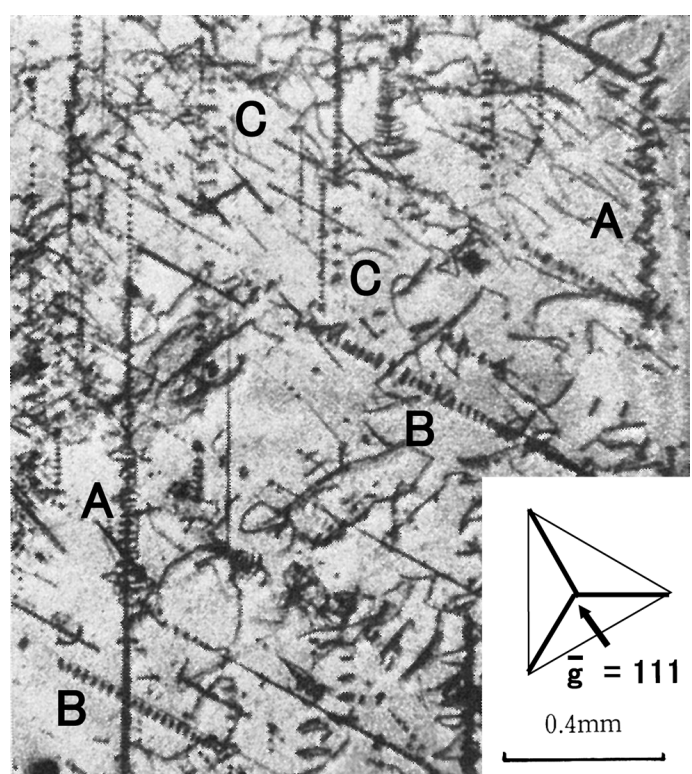

図 3 純アルミニウム単結晶の転位 A：ヘリカル転位 (Helical Dislocation, HD), B：プ リズマティック転位ループ列（Row of Prismatic Dislocatio Loop, RPDL)，C：ランダム形状の転位 (Randomly Curved Dislocation, RCD)

3 中の C など, 以後 RCD 転位と表記する)

十分焼なまししたアルミニウム中の個々の転位をXTに よって最初に観察したのは Lang ら ${ }^{18)}$ である。その結果によ れば，特定の形状を持たない RCD 転位のほかに, 純金属では 通常見られない $\mathrm{HD}$ 転位や RPDL 転位が存在し, それらの径 はしばしば数十 $\mu \mathrm{m}$ に達する(いずれも〈110〉方向を軸とす る。）その後いくつかの研究グループによっても同様の観察が 行われ, 異なる形状の転位の発生・消滅の過程か議論されて きた20) 26)。

$\mathrm{HD}$ 転位や RPDL 転位について今日までに明らかにされて いるのは，打扮む称次のことである。

（a）冷却過程において臨界の空孔過飽和度の下で発生す $3^{19)}$ 。

（b）徐冷却（冷却速度 $<10^{-3} \mathrm{~K} / \mathrm{s}$ ）によって発生が最小限に とどめられ，室温で低転位密度が得られる 20) 24)。

(c) 約 $500 \mathrm{~K}$ 以上では熱的に極めて不安定であり, 数分間 以内に消失する ${ }^{22) ~ 24) 。 ~}$

一方, 特定の形状を持たない通常の転位についての報告は 少なく, わずかに高温から冷却した結晶の室温での転位密度 は冷却速度に依存するという結果が報告されているのみであ る $^{14,24)}$ 。

次節では HD 転位や RPDL 転位の発生・消滅過程, つづい て特定の形状を持たない転位（RCD 転位）の消滅過程につい て述べる。

\section{2 加熱·冷却中の転位の発生・消滅過程}

加熱・冷却中の過（未）飽和原子空孔の存在によって生じ る熱力学的な力の働きによる転位の発生過程を取扱う。

図 4 (A) に示す一連のセクショントポグラフは熱サイク ル焼なまし中の転位の生成・消滅過程を追跡したものであ る ${ }^{25)}$ 。下のグラフの横軸は焼なまし時間を示し, 縦軸は RCD 転位密度 (B), RPDL 転位密度 (C), および温度 (D) を示 

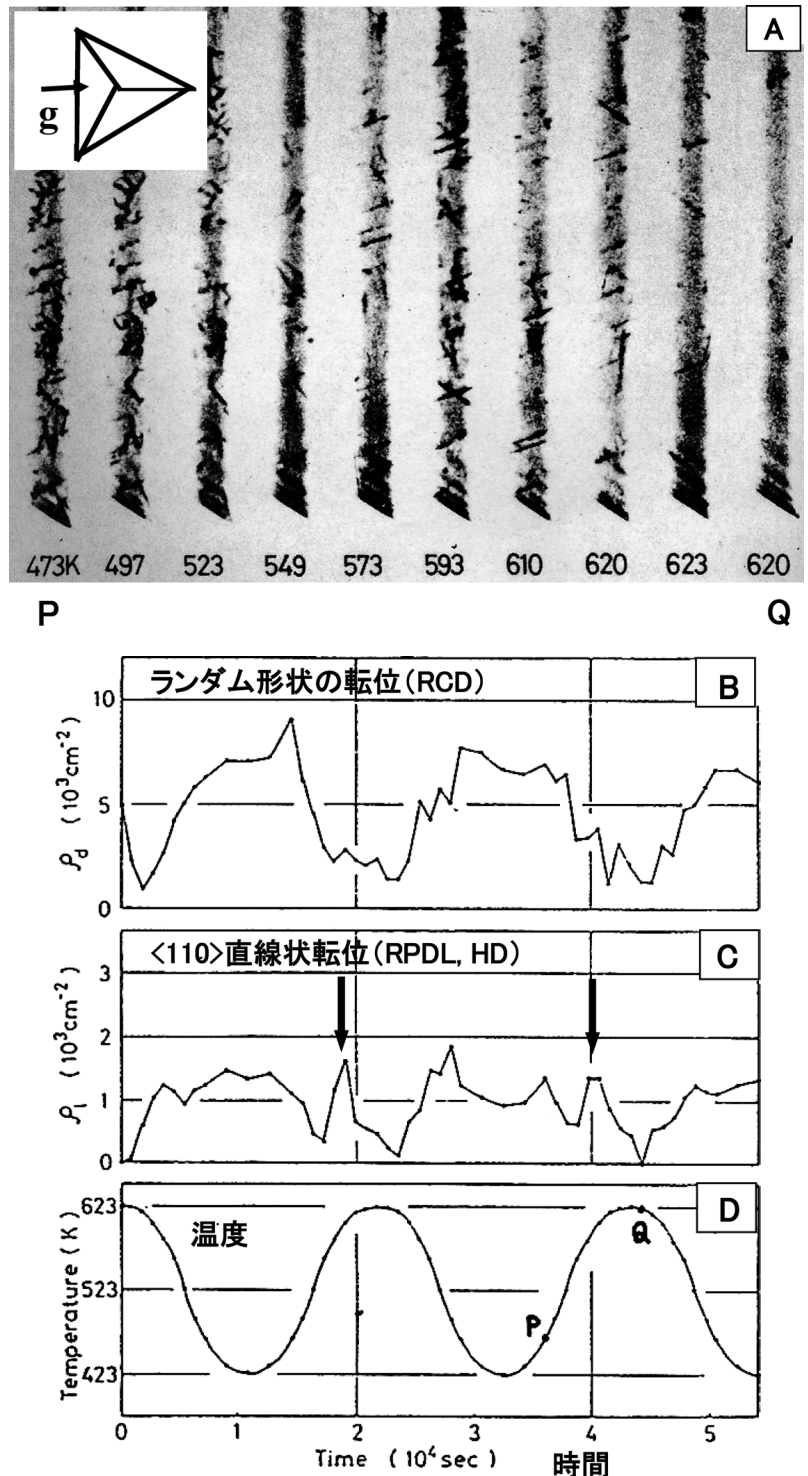

図 4 熱サイクル焼なましにおける転位組織の変化 $\mathrm{A} ： セ ク シ ョ ン ト ホ ゚ ク ゙ ラ フ ， \mathrm{~B} ： \mathrm{RCD}$ 転位の密度, C：RPDL，HD の密度， D：温度（熱サイクル： $623 \sim 423 \mathrm{~K}, 4 \mathrm{~h} /$ cycle)

す。（温度－時間曲線上の $\mathrm{P}$ 点から $\mathrm{Q}$ 点までがトポグラフの $\mathrm{P}$ から $\mathrm{Q}$ までに対応する。） $\mathrm{RCD}$ 転位密度は温度の上昇・下 降に対応して減少・増大しているが，RPDL 転位の密度は上 昇時（空孔濃度は未飽和状態と推定される）に鋭いピークを 示しているようにみえる。これは格子間原子型の RPDL 転位 が形成されたことを示唆している25),26)。

図 5 に示す一連のセクショントポグラフは室温から $400^{\circ} \mathrm{C}$ まで $100^{\circ} \mathrm{C}$ ずつ段階的に昇温し(平均昇温速度 $\approx 260^{\circ} \mathrm{C} / \mathrm{h}$ ), $400^{\circ} \mathrm{C}$ に約 $150 \mathrm{~min}$ 保持した後, 段階的に $280^{\circ} \mathrm{C}$ まで冷却し (平均冷却速度 $\approx 100^{\circ} \mathrm{C} / \mathrm{h}$ ), その後室温まで炉中冷却した結 果を示している ${ }^{24)}$ 。各セクショントポグラフの撮影時間は $10 \mathrm{~min}$ である。図の左上に（111）面の正 4 面体と $\boldsymbol{g}=\langle 111\rangle$ （回折ベクトル）を示した。左下部の矢印で示すように左上 から右下へ向かう〈110〉方向に沿った直線状イメージ（あ るいは点状イメージのつながり）をRPDL 転位と判断した。 RPDL 転位は一つの〈110〉方向に沿っていることがわかる。 析出物などから熱膨張の差などによって複数の〈110〉方向

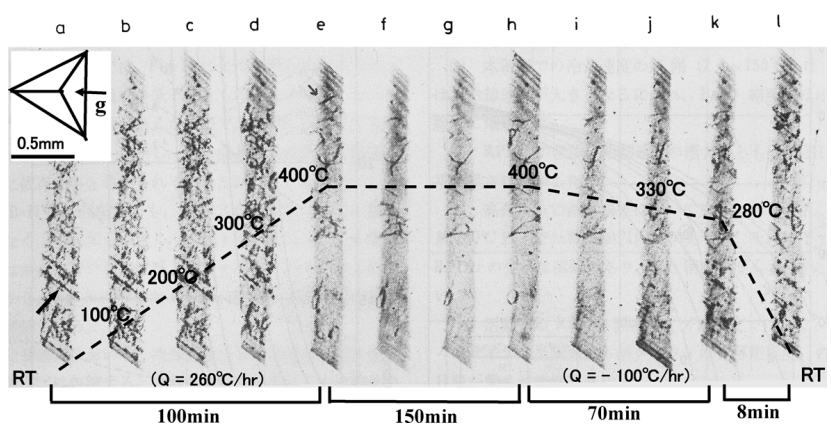

図 5 加熱・冷却中の転位の消滅・発生

にパンチアウトされているのではない。このことはある種の Climb Source（上昇運動によって増殖する転位源, B-H 源) が活動したことを示唆し, そのサイズはXT の分解能以下で あるということになる。

B-H 源の活動に影響する因子は，（i）空孔の過（未）飽和 度,（ii）B-H 源の性格，（iii） B-H 源以外の空孔の発生・消 滅場所の性格, である。いずれの因子も不確定な要素を含ん でいるので, 一般的には, 定量的な考察を進めることは困難 である。観察結果の解釈に関しては, 冷却・加熱過程の空孔 の過（未）飽和度を計算し，その結果に基づいて B-H 源の サイズや活動温度域が推定されている。一定温度領域を通過 する際の冷却速度を制御することによって B-H 源の活動を抑 制し，極低転位密度を得ることも期待できる。

刃状転位での非平衡空孔の吸収・放出によって空孔の化学 ポテンシャルが変化し, 転位の自由エネルギーも変化する。 結果として次式で示す熱力学的な力, $f_{c}$, が単位長さの転位 に働く16)。

$$
f_{c}=-(k T b / \Omega) \ln \left(C / C_{0}\right)
$$

この力と転位の線張力とのつり合いの関係から, B-H 源が活 動するための臨界条件，式 (2)，が導かれる。

（3）式に従えば， $\mathrm{Al}$ 結晶の $600 \mathrm{~K}$ から室温への急冷によっ て空孔が凍結されるとすれば, $\ln \left(C / C_{0}\right) \sim 100 b / L$ となる。こ こで, $k T \sim 0.05 \mathrm{eV}(600 \mathrm{~K}), 0.025 \mathrm{eV}(300 \mathrm{~K}) 。 \mathrm{Al}$ では, $\mu b^{3} \sim$ $3.8 \mathrm{eV}$ 。したがって, 長さ $L=10^{4} \mathrm{~b}(\sim 2.5 \mu \mathrm{m})$ の B-H 源は過 飽和度 $C / C_{0} \sim 1.01$ で活動することになる。この程度の過飽和 度は実際の焼入れや急冷実験において達成可能である。

低転位密度の板状アルミニウム単結晶を高温から冷却した 場合の原子空孔濃度は, 温度, 冷却速度, 板厚中心からの 位置などの関数として数值計算によって推定することができ $3^{24), 28)}$ (原子空孔の消滅場所や湧源が板の表面のみであると 仮定されている)。図 6 に冷却中の板厚中心の空孔過飽和度 之上述の B-H 源が活動するための臨界空孔過飽和度の計算 結果の例を示す。グラフから, $423^{\circ} \mathrm{C}$ から $50^{\circ} \mathrm{C} / \mathrm{h}$ で冷却すれ ば $\mathrm{B}-\mathrm{H}$ 源（長さ $l=0.1 \mu \mathrm{m}$ ）が $300^{\circ} \mathrm{C}$ 付近で活動することがわ かる。このときの空孔過飽和度は $\ln \left(C / C_{0}\right)=1.4$ である。

以上のことから, 冷却中の RPDL 転位の発生を防ぐために は臨界速度以下での室温までの冷却が必要ということになる が，図 5 からもわかるように， $280^{\circ} \mathrm{C}$ から室温への急冷によっ て発生する RPDL 転位は非常に少ない。この温度域では原子 拡散速度が小さく, たとえ臨界空孔過飽和度が満たされてい ても RPDL 転位の発生が抑制されるためと考えられる。した 


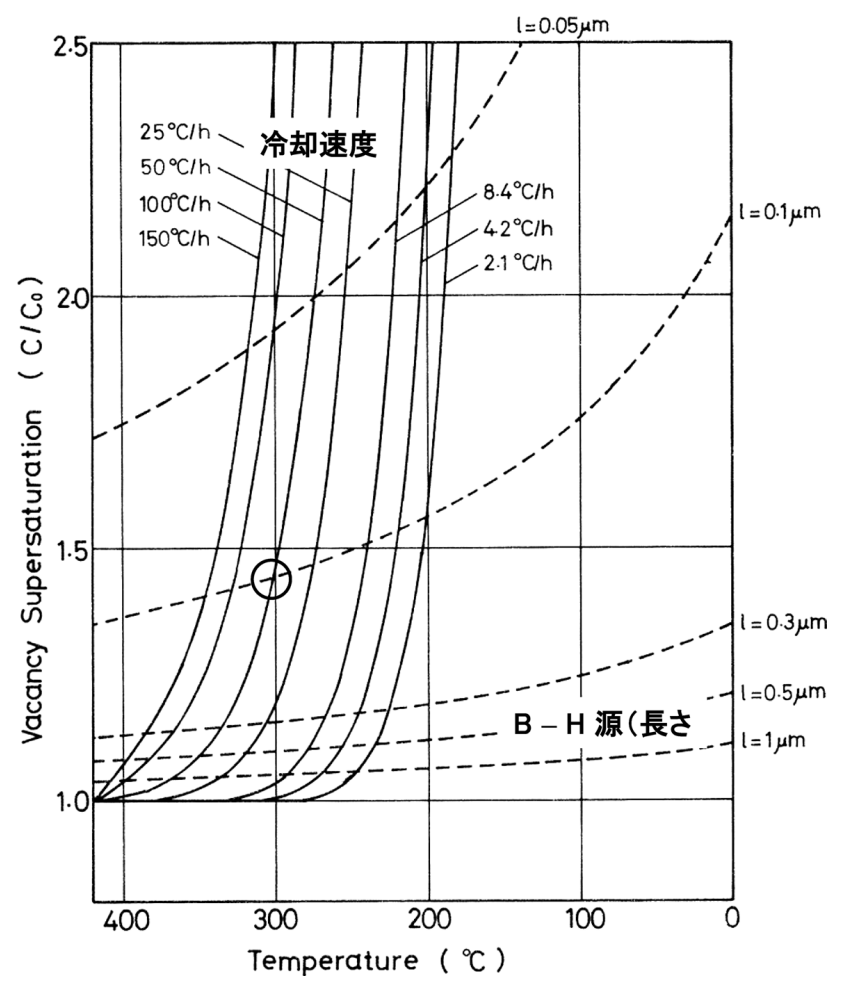

図 6 過剩空孔濃度と温度の関係
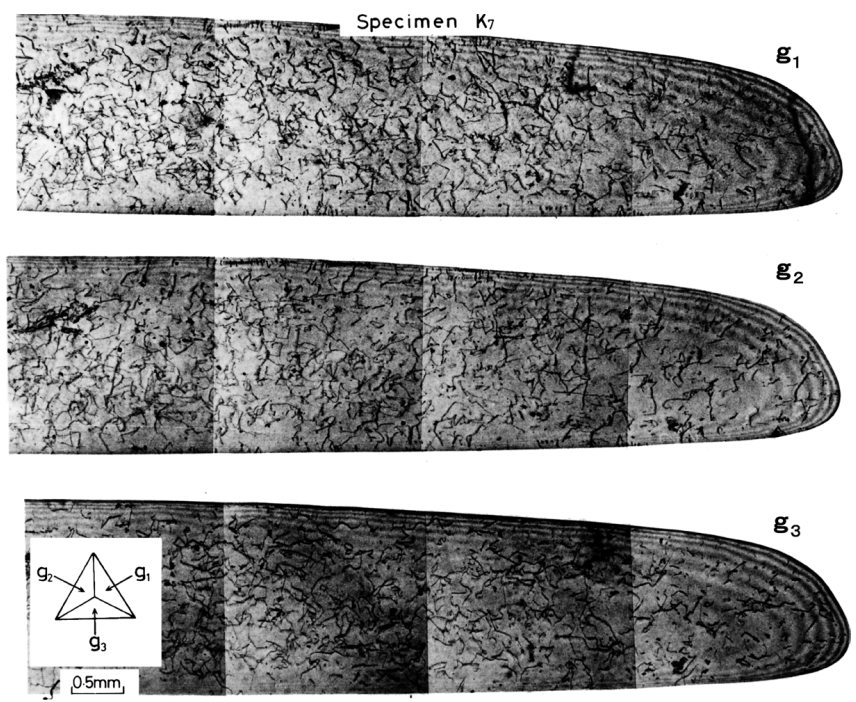

図 7 純アルミニウムバルク単結晶の転位 高温長時間焼なまし後徐冷 $\left(60^{\circ} \mathrm{C} / \mathrm{h}\right)$

がって，高温 $\left(400^{\circ} \mathrm{C}\right.$ 以上）長時間の焼なましによって低転 位密度状態を得た後, $300^{\circ} \mathrm{C}$ 付近まで十分な徐冷却を行い, その後室温まで炉中冷却することによって転位密度が低い, 完全度が高いアルミニウム結晶が得られることが期待される。 図 7 はこのような熱処理によって得られた結晶のプロジェク ション・トポグラフである。亜結晶粒界や RPDL 転位は存在 せず特定形状を持たない RCD のみ観察される。転位密度は $10^{3} \mathrm{~cm} / \mathrm{cm}^{3}$ 程度である。

\section{3 特定の形状を持たない転位（RCD 転位）の等温焼な まし中の消滅過程 29$)$}

高温・長時間の焼なましによって得られる完全度が高い結 晶では空孔濃度がほぼ平衡状態に保持されているので, RPDL

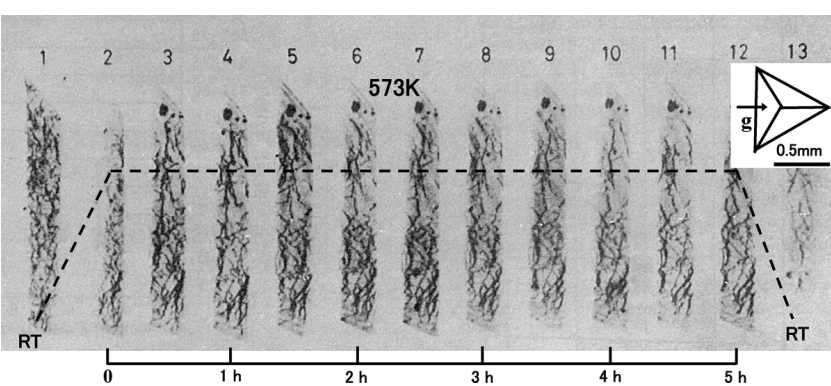

図 8 等温焼なましにおける転位の消滅過程

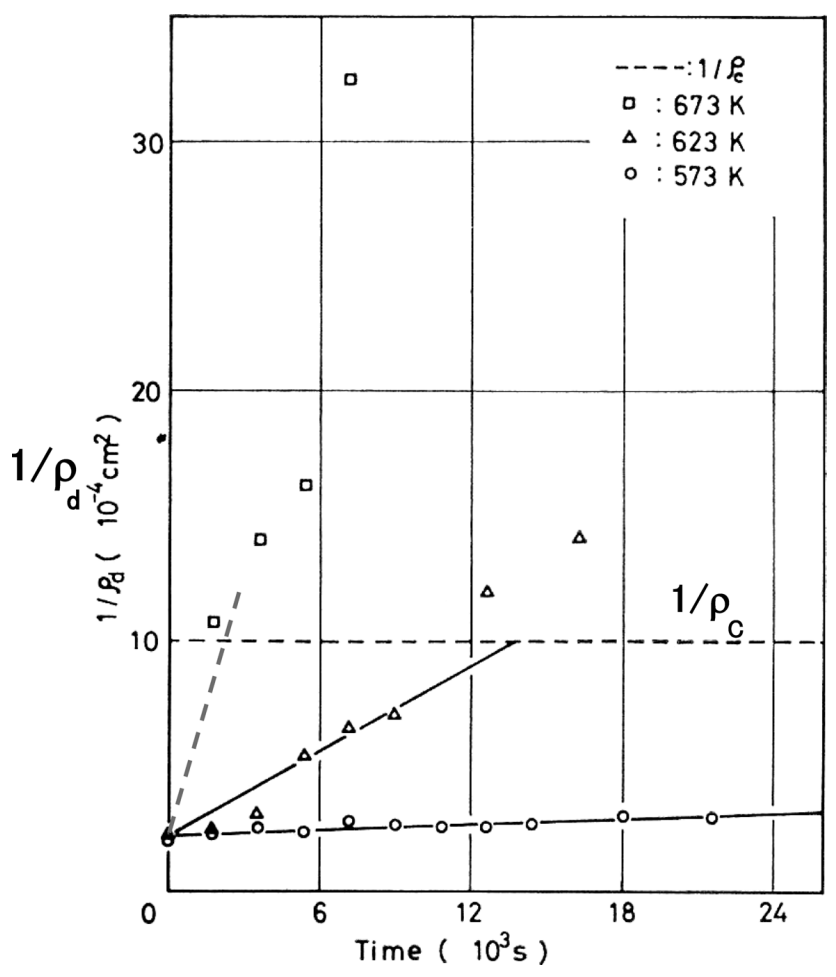

図 9 転位密度の逆数 $\left(1 / \rho_{\mathrm{d}}\right)$ と焼なまし時間 $(\mathrm{t})$ の関係 $\rho_{\mathrm{C}}$ : 網目サイズと試料厚さが等しくなる場合の臨 界転位密度

転位や $\mathrm{HD}$ 転位はほとんど含まれず， RCD 転位のみが存在す る。これら RCD 転位の密度も焼なまし時間の経過とともに低 下することが期待される。セクショントポグラフィによって その過程を追跡した結果を図 8 に示す（試料面：(111), 写 真の上下方向 : $\langle 110\rangle$, 左右方向 : $\langle 112\rangle, \boldsymbol{g}=[111]$, 保持温 度：573K)。HD 転位や RPDL 転位は消失し, RCD 転位のみ が観察される。

同様の観察を $623 \mathrm{~K}$ および $673 \mathrm{~K}$ でも行って, 各温度での 転位密度の变化をプロットしたものが図 9 である。各温度に おいて, 転位密度の逆数は焼なまし時間に対してほぼ直線的 に变化している。図中の $\rho_{\mathrm{C}}$ は臨界転位密度（後述）を表す。

次に観察結果の解析を試みる。一般に焼なましによって転 位密度がある程度低下した後は転位は網目構造を形成してい ると考えられている。さらに焼なまし時間が経過すれば網目 サイズ（L）が大きくなり，その結果転位密度は低下する。 この過程は Friedel ${ }^{30)}$ によれば, 転位の上昇運動による網目 の膨張過程と考えることができる。つまり, 刃状成分の上昇 運動に必要な原子空孔の吸収・放出が網目を形成する転位の 
線張力によって誘起されるとすれば，転位網の膨張速度が次 のように求まる。

$$
d L / d t=\left(D C_{\mathrm{j}} / b\right) /(W / k T)=\mu b^{3} D C_{\mathrm{j}} / L k T
$$

ここで, $L$ : 網目サイズ, $W$ : 線張力による仕事, $t:$ 時間, $k$ : ボルッマン定数, $D$ : 自己拡散係数, $T$ : 絶対温度, $C_{\mathrm{j}}$ : ジョグ濃度， $\mu$ : 剛性率， $b$ : バーガースベクトルである。転 位が 3 次元的な網目を形成している場合の転位密度 $\left(\rho_{\mathrm{d}}\right)$ は,

$$
\rho_{\mathrm{d}}=K L^{-2}(K=\text { const. }=1 \sim 2)
$$

で表されるので, 式（1）から次式が導かれる。

$$
d\left(1 / \rho_{\mathrm{d}}\right) / d t=(2 / K)\left(\mu b^{3} / k T\right) D C_{\mathrm{j}}
$$

式（6）は $T=$ const.において， $1 / \rho_{\mathrm{d}}$ と $t$ が直線関係を持つこと を示している。 $\left(1 / \rho_{\mathrm{d}}\right)-t$ の勾配（ $\left.\alpha\right)$ は,

$$
\begin{aligned}
\alpha & =\left(2 / \mu b^{3} / K k T\right) D C_{\mathrm{j}} \\
& =\left(2 / \mu b^{3} / K k T\right) D_{0} C_{\mathrm{j} 0} \exp \left\{\left(-\left(E_{\mathrm{D}}+E_{\mathrm{j}}\right) / k T\right\}\right.
\end{aligned}
$$

で表される。ここで， $E_{\mathrm{D}}$ は自己拡散の活性化エネルギー, $E_{\mathrm{j}}$ はジョグ形成の活性化エネルギー, である。したがって, $\ln (\alpha \mathrm{T})$ と $(1 / T)$ のプロットから, 活性化エネルギー $\left(E_{\mathrm{D}}+E_{\mathrm{j}}\right)$ が求まる。

網目のサイズが試料の厚さ $(0.3 \mathrm{~mm})$ にほぼ等しくなれば 網目構造は崩壊すると考えられるので，(5) 式に基づいて推 定した臨界転位密度 $\left(\rho_{\mathrm{C}} \sim 10^{3} / \mathrm{cm}^{2}\right)$ の範囲内で（6）式およ び（7）式による解析が可能となる。解析した結果, 活性化エ ネルギー $\left(E=E_{\mathrm{D}}+E_{\mathrm{j}}\right)$ は $1.8 \mathrm{eV}$ と求められた。 $E_{\mathrm{D}}=1.47 \mathrm{eV}$ と すれば, $E_{\mathrm{j}}=0.3 \mathrm{eV}$ となる転位ジョグの形成エネルギー $\left(E_{\mathrm{j}}\right)$ について過去には理論的にも実験的にも正確な值は報 告されていないが，通常の金属では $1 \mathrm{eV}$ の何割かであるとい われている30) ので, 理解できる值といえる。一方, 結晶を室 温へ冷却した後のトポグラフ上の転位線分の方向 $(n)$ とバー ガースベクトル $(b)$ との角度関係を調べた結果, 全体的に転 位が刃状成分に富んでいることが明らかとなった（詳細な データについては原論文 ${ }^{29)}$ 参照)。これは焼なまし中にらせ ん転位が, 刃状転位に比べて, 容易に対消滅あるいは結晶の 外へ消失した結果だと考えられる。また， $(b \times n)$ が〈111〉 から偏移していることも明らかになった。これは転位線分が 一枚の $\{111\}$ 面に乗っていないこと, つまり転位が高濃度の ジョグを含んでいることを示すあのであり，焼なまし中に転 位が活発な上昇運動を行ったことを物語っている。

\section{4 この章の終わりに}

これまで示したように，アルミニウム中の転位は外力の下 で F-R 源の活動によって増殖するのみでなく, 加熱・冷却速 度が十分に大きく, 原子空孔濃度が種々の B-H 源 (Climb Source）が活動するための臨界值を超えた場合にも発生する。 したがって, 高温長時間の焼なましによって低転位密度を達 成した後，冷却速度を制御することによって B-H 源の活動を 抑制することができれば室温で低転位密度の結晶が得られる (网 7)。

一方，高温焼なましによってある程度転位密度が低下した 場合, 転位は網目構造を形成しており, ある程度の網目サイ ズにおいては, 転位密度の低下過程を網目の膨張過程（網目 サイズの増大過程）として解析することができる。その場合,
転位密度の逆数は焼なまし時間に対して直線的に变化する。

\section{Berg-Barrett 法による観察に基づく純アルミニ ウム単結晶の高温引張变形組織の解析}

金属材料の高温变形挙動の特徵を理解することは, 材料の 選択や設計のみならず材料製造にあたって適切な条件を設定 するための不可欠の基礎的知見となる。材料の高温变形中に は加工硬化と同時に焼なましによる復旧過程を通して軟化が 進行する。単純に考えれば, 加工硬化は転位密度の上昇に よってもたらされ, 軟化は転位密度の低下による。両者の速 度が等しくなれば加工硬化 $(d \sigma)$ はゼロとなり, 定常変形状

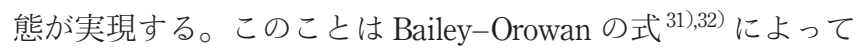
表現されている。

$$
d \sigma=h d \varepsilon^{-r} d t
$$

ここで, $h d \varepsilon$ : 塑性ひずみによる増加, $r d t$ : 焼なまし効果に よる減少, である。この式はアルミニウムのように転位の運 動に対する有効応力がきわめて小さい場合に有効である。

変形中の組織変化に関しては, 転位密度の上昇に伴って亜 結晶粒組織が形成されることが明らかにされ, さらに巠結晶 粒界の両側の結晶の方位差や亜結晶粒サイズなどが变形条件 との関係において調べられてきた。

变形中の復旧過程が回復現象のみによる場合を動的回復型 とよび，再結晶現象を伴う場合を動的再結晶型として金属を

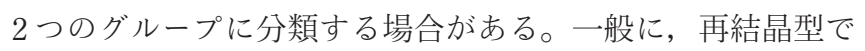
は定常変形状態は現れず, 応力ーひずみ曲線は大きく波打 つ。従来多くの実験デー夕に基づいて, 積層欠陥エネルギー の大小が動的回復型と動的再結晶型とを分ける重要因子と考 えられていた (例えば $\left.{ }^{33}\right)$ )。純アルミニウムは, クリープ試 験や引張試験デー夕に基づいて, 他の高積層欠陥エネルギー 金属と同様に, 動的回復型に属すると考えられてきた（アル ミニウムの積層欠陥エネルギー : $\left.166 \mathrm{~mJ} / \mathrm{m}^{2}\right)$ 。以下に X 線回 折顕微法（Berg-Barrett 法）を使って著者らが行った純アル ミニウム単結晶の高温引張変形組織の解析例を示す ${ }^{34), 35)}$ 。

試料および実験条件： $5 \mathrm{~N}$ 純度の帯精製アルミニウムイン ゴットを種結晶として軸方位〈123〉および〈111〉の角柱状 単結晶をブリッジマン法で作成し, これより引張試験片を切 出した。(ゲージ長： $30 \mathrm{~mm}$, 断面 : $4 \times 3 \mathrm{~mm}^{2}$ ) インストロン 型試験機（TOM500）を使用し, 開閉型炉を用いて大気中で 引張試験を行った後, 室温へ急冷した。試験温度：773 873 $\mathrm{K}$, 初期ひずみ速度 : $5.6 \times 10^{-5} \sim 5.6 \times 10^{-3} \mathrm{~s}^{-1}$ 。所定の变形段 階で試料の転位組織を XT（Berg-Barrett法, X 線源 Fe $K \alpha_{1}$ 線， $\lambda=0.1936 \mathrm{~nm}, \boldsymbol{g}=\overline{3} 1 \overline{1})$ によって観察した。B-B写真で は亜結晶粒界は回折ベクトルとの関係から, 強いコントラス ト (黒), あるいは弱いコントラスト（白）として観察され る。亜結晶粒界の転位構造の観察には TEM（JEOL-1000）を 用いた。さらに亜結晶粒界の両側の結晶の傾きやずれ角の測 定には ECP (Electron Channeling Pattern) を利用した。

応力ーひずみ曲線; 本研究の条件で得られた真応力ー真ひ ずみ曲線はひずみ約 $15 \%$ までの範囲で応力ピークを含まず, 回復型を示した。ひずみ速度式, $\varepsilon=A \sigma^{\mathrm{m}} \exp (-Q / R T)$ に 従って解析した結果, 軸方位〈123〉結晶については $m=3.9$, $Q=30 \mathrm{kcal} / \mathrm{mol}(126 \mathrm{~kJ} / \mathrm{mol})$, また〈111〉結晶については $m=$ $5.8, Q=32 \mathrm{kcal} / \mathrm{mol}(134 \mathrm{~kJ} / \mathrm{mol})$ を得た。 $m$ および $Q$ の值は, 

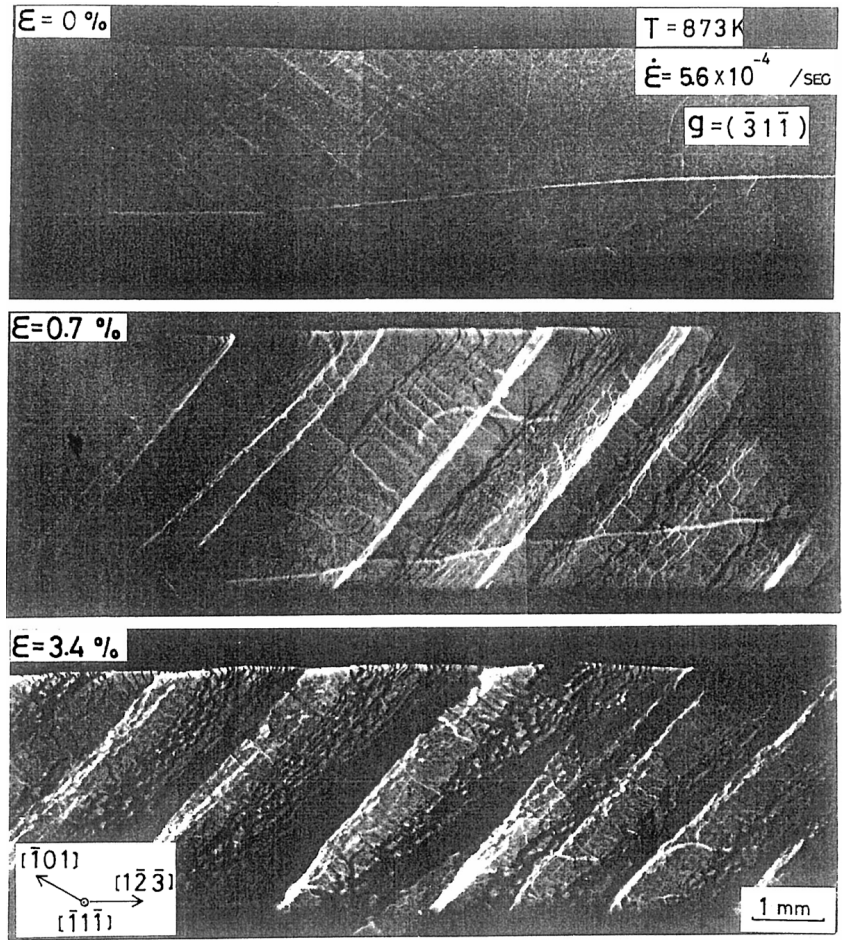

図 10 純アルミニウム単結晶の高温引張変形組織（回復 組織の B-B 写真)

試料：単結晶 $5 \mathrm{~N}$ 帯精製インゴット，ブリッジマ ン法 (種結晶)

引張試験片 : ゲージ長 $30 \mathrm{~mm}$, 断面 $4 \mathrm{~mm} \times 3 \mathrm{~mm}$ 引張試験：大気中, $773 \sim 873 \mathrm{~K}$

初期ひずみ速度 : $5.6 \times 10^{-5} \sim 5.6 \times 10^{-3} \mathrm{~s}^{-1}$

Berg-Barrett 法 : $\mathrm{Fe} K \alpha_{1}$ 線, $\lambda=0.1936 \mathrm{~nm}, \boldsymbol{g}=\overline{3} 1 \overline{1}$

これまでに報告されている值（ $m \sim 5, Q \sim 130 \mathrm{k} \mathrm{J} / \mathrm{mol} ）$ とおお むね一致する。

変形組織 : 变形を途中で中断し，急冷した後に室温で撮影 したXT を図 10 に示す (〈123〉結晶の場合)。〈123〉軸方位 の結晶の引張变形初期には一次すべり系転位の運動が優先す る。未変形状態で一次すべり方向， [101]，に沿って弱いす ベり帯が形成されている（試料調整段階でのミスハンドリン グによると考えられる）。 $e=0.7 \%$ （せん断ひずみ $\gamma=1.5 \%$ ）で は一次すべり面トレースに垂直な方向にポリゴニゼーション 壁が形成され，結晶は細長い巠結晶粒に分割されるようにな る。(トポグラフの右上から左下に向かって白い帯と黒い帯 が交互に数百 $\mu \mathrm{m}$ の間隔で存在している。变形の進行ととも に二次すべり系転位によって形成された亜結晶粒界が一次す ベり系転位によるポリゴニゼーション壁に垂直にそれらを橋 渡しするように形成されている。 $e=3.4 \%(\gamma=7 \%)$ では亜結 晶粒への分割はさらに進み，結晶の長手方向に沿ってほぼ等 間隔に正負のポリゴニゼーション壁（PW）が形成されるよ うになる。結晶の両端では，つかみの効果によって二次系転 位の運動が活発になり, より複雑な亜結晶粒界構造が発達す ると考えられる。

$e=3.4 \% \quad(\gamma=7 \%)$ の段階において, 一つの PW の両側の結 晶の方位差測定 (ECP 法), および PW 構成する転位の バーガースベクトルを決定（TEM）した結果を要約すれば, 以下のと抢りである。（i）正負の PW 壁の間隔は約 $2 \mu \mathrm{m}$ であ り，壁の両側の結晶の方位差は，一次すべり系刃状転位腺の

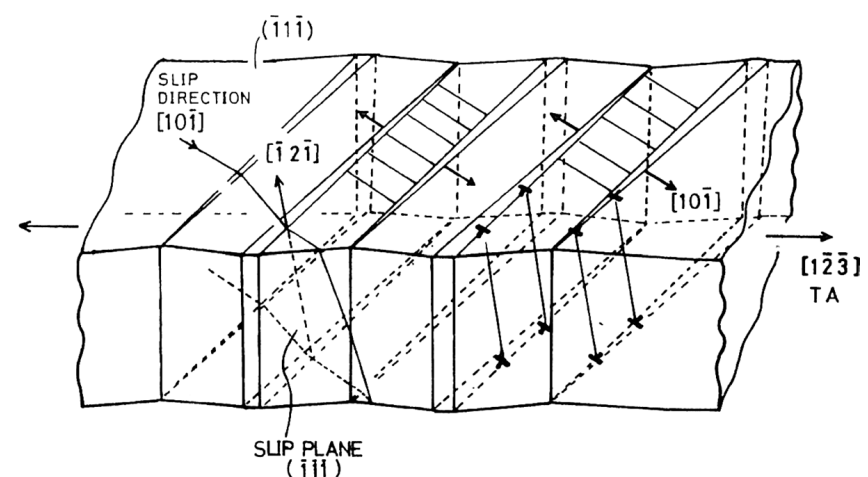

図 11 単一すべり方位単結晶の高温变形組織（亜結晶 粒組織の模式図)。一次すべり系転位で構成され る亜結晶粒界が発達, 結晶は幅 $1 \mathrm{~mm}$ 程度の細長 い直方体領域に分割される，亜結晶粒界での方位 差は最大 $2 \sim 3^{\circ}$

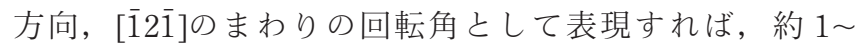
$1.5^{\circ}$ である。（ii） PW 壁は一次すべり系転位のバーガース・ ベクトル $(b=[101])$ に垂直であり, 主として一次すべり系 刃状転位で構成される典型的な PW 壁である。また転位間距 離に基づいて計算した方位差は $2 \sim 3^{\circ}$ である。 ECP パターン を利用して決定した方位差とはやや異なるが，個々の PW 壁 での角度差の違いを考慮すれば，理解の範囲にとどまる。

以上の結果に基づいて, 単一すべり方位純アルミニウム単 結晶の高温引張変形の定常状態で形成される（e=3.4\% $(\gamma=7 \%)$ 亜結晶粒組織を模式的に表現したものを図 11 に示 した（比較的低角度と考えられる二次系転位による巠結晶粒 界を省略した)。

一方，多重すべり方位の場合は変形初期から複数のすべり 系が活動するので，変形中に形成される巠結晶粒の形状はよ り等方的になるが，それらの転位構造はさらに複雑になる。

以上のように, クリープ変形などの高温変形中に形成され る組織を X 線回折法や電子顕微鏡によって実際に解析し, PW の性格を明らかにした例は非常に少ない。

\section{5. 放射光ラウエ法その場測定による純アルミニウム 単結晶の高温圧縮変形中の再結晶発現の直接的 証査}

前章で述べたように，アルミニウムの高温変形中の復旧過 程は回復型であると考えられてきた。しかし，1990年代に Yamagata ${ }^{36)}$ 38) によって高純度単結晶の圧縮变形において応 力振動が測定され，さらに応力ピーク後に伸びのない X 線ラ ウエ・スポットが観察されるに及んで，積層欠陥エネルギー の大小のみによる分類は十分ではなく, 結晶の純度之深く結 びついた結晶粒界の易動度む重要な因子であることが認識さ れてきた ${ }^{39)}$ 。また，引張試験においても動的再結晶型の応力 振動が認められた ${ }^{40)}$ 。著者ら屯 X 線源として放射光を利用す ることによって時間分解能を大幅に改善し, 応力ひずみ曲線とラウエ斑点の同時測定を行うことによって, 圧 縮変形中の再結晶発現のより直接的な証左を得た。本稿では 原論文 ${ }^{41)}$ の中から中心的なデー夕のみを抽出し, 簡単に紹介 する。

試料：(株) 大阪アサヒメタル工場製の帯溶融精製した 99.999 mass\%（5N-Grade）アルミニウム単結晶である。微量 
の銅 $(\mathrm{Cu})$ ，マグネシウム $(\mathrm{Mg})$ 打よびシリコン $(\mathrm{Si})$ が含 まれている。圧縮軸方向を〈111〉近傍に定めた $3 \times 3 \times 6 \mathrm{~mm}^{3}$ の角柱状試料を切出し, 圧縮試験片とした。

実験条件：〈圧縮試験〉小型圧縮試験機を作製し, 透過 Laue スポットの撮影々応力ーひずみ曲線の測定を同時に行っ た。試験温度は 393 508K, 初期ひずみ速度は $10^{-5} \sim 10^{-2} \mathrm{~s}^{-1}$ である。また，種々の变形条件（温度，ひずみ速度）での応 カーひずみ曲線を得るために市販のインストロン型万能試験 機を使用した。

〈透過ラウエ法〉短時間で Laue パターンを撮影する目的で 放射光を利用し，透過 Laue スポットその場ビデオ撮影を行っ た。財団法人高輝度光科学研究センター（SPring-8）のビー ムライン BL28B2 を利用し，低エネルギー放射光 $(<3 \mathrm{keV})$ をべリリウム（Be）空で吸収し，除いた。ビームの発散角は $0.024 \mathrm{mrad}$, ビーム照射領域は試料中央部，ビームの断面形 状は正方形で，照射面積は $4.0 \mathrm{~mm}^{2}$ である。透過 Laue スポッ トの形成に寄与する領域（照射体積）は試料体積の約 30\% であった。变形中，蛍光板に映った放射光透過 Laue スポッ トを CCD カメラによりビデオ撮影した。試料と蛍光板の距離 は $140 \mathrm{~mm}$ である。この方法により Laue・スポット撮影の時 間分解能を 1 秒以下にすることができた。従来の X 線管球と $\mathrm{X}$ 線フィルムの組合せでは約 1 分, 回転対陰極型 $\mathrm{X}$ 線発生装 置とイメージングプレートでは 5 秒程度である。

応力 -ひずみ曲線：圧縮軸〈111〉, 試験温度 393 508K, 初期ひずみ速度 $1.50 \times 10^{-5} \sim 1.00 \times 10^{-3} \mathrm{~s}^{-1}$ の条件での圧縮試験 によって得られた応力ーひずみ曲線には動的再結晶型の応力 振動が現れた。第一ピーク応力值に対して求めた動的再結晶 発現のための見かけの活性化エネルギー, $Q$ は $65.2 \mathrm{~kJ} \cdot \mathrm{mol}^{-1}$ であった。これはアルミニウムの大傾角粒界の移動のための 活性化エネルギー ${ }^{42)} 63 \mathrm{~kJ} \cdot \mathrm{mol}^{-1}$ に近く，核形成後の粒成長は 大傾角粒界の移動を伴って進行することを示唆する。しかし, Yamagata と Otsuka ${ }^{43}$ が求めた 99.999 mass\% 〈111〉方位アル ミニウム単結晶の見かけの活性化エネルギー $140 \mathrm{~kJ} \cdot \mathrm{mol}^{-1}$ に 比べて差があり，この原因は不明であり，さらに検討する必 要がある。

次に透過 Laue スポットの撮影と同時に測定した真応力ー 真ひずみ曲線を図 12 に示す。真ひずみ $\varepsilon=0.15$ で最初の明瞭 な第一応力ピークの出現が認められた。第一応力落下に打け る応力の变動幅（9.2 MPa）はピーク応力（17 MPa）の約 55\% であった。このとき試料内のかなりの量のエネルギーが解放 されたことが示唆される。その後の応力落下では, 応力の変 動幅は第一応力落下におけるものよりも小さいものであった。

高温変形中における結晶方位変化：ビーム入射方向は [2113］方向，圧縮軸は［1111］方向である。放射光透過 Laue スポットのビデオ像を各変形段階において抜粋したものを図 13 に示す。図中の各写真の下段に真ひずみおよび圧縮試験開 始時からの経過時間を記した。左上の番号は図 12 中の番号 に対応する。変形が進むに従って, 蛍光板上で各スポットは 放射状に伸びた。これは試料内部のビーム照射領域において, 変形の進行に伴って結晶格子面が湾曲したことを示している。 $\varepsilon=0.15$ (圧縮試験開始から 149 秒後）で，伸びのない新しい スポットが現れた（図 13 の 4 の矢印先端部分など）。未再結 晶領域の伸びた 311 スポットの端（図 13 の矢印先端部分）が 急激に輝度を増している。同様の現象は未再結晶領域のほか

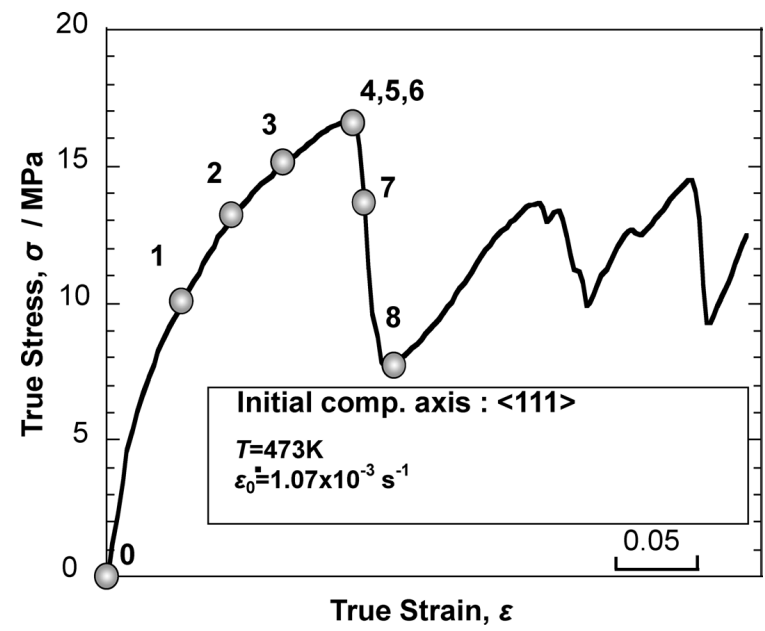

図 12 純アルミニウム単結晶の高温圧縮試験における応 力ーひずみ曲線。曲線上の数字 $0 \sim 8$ は（図 13） の透過 Laue 写真の番号に対応
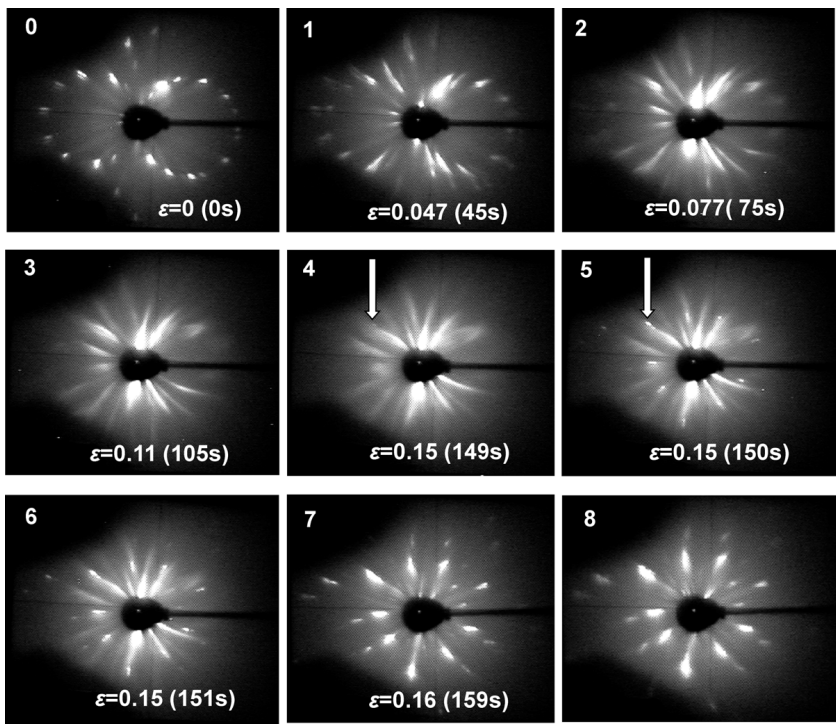

図 13 高温变形中の透過 Laue 斑点の形状变化。写真左 上の数字 $0 \sim 8$ は（図 12）の応力 -ひずみ曲線上 の番号に対応

のスポットでも観察された。第一応力落下は $\varepsilon=0.15$ (圧縮試 験開始から 150 秒後) で発現したことから, 新スポットは応 カピーク到達の遅くとも 1 秒前にすでに発現していたと言え る。試料は単結晶であるので, $\varepsilon=0.15$ で発生した新スポット は動的再結晶によって生成した新粒のスポットであると言え る。すなわち, 変形応力の急激な落下は動的再結晶の発現に よるあのと結論することができる。

\section{6. おわりに}

$\mathrm{X}$ 線回折法を利用したアルミニウムの微細組織研究に関し て筆者らの 2,3 の成果を中心に簡単なレビューを行った。

X 線回折顕微法による個々の転位の観察は完全度が高い結 晶のみに適用されうる。アルミニウムの場合, 低転位密度結 晶を作製することにエネルギーと時間を要するが，バルク単 結晶試料の欠扸観察法としてほかに類がない。ラウエ法は基 本的で比較的に簡便な方法であるが, 得られる情報は示唆に 
富み, 研究目的が明確である限り, 効果的かつ魅力的である。 $\mathrm{X}$ 線回折顕微法（XT）の応用におけるその後の進歩には著 しいものがある。XTの工業的な応用は主としてシリコン （Si）などの半導体の結晶性評価において行われている。現在 は平行性のよい超強力 $\mathrm{X}$ 線源である放射光の利用が普及し, XTに限らずトモグラフィなどにおいても利用されている44)。 一方, 画像観察・計測技術の進歩も著しい。精密卜ポグラ フィの分野においては, 格子欠陷や格子面のひずみを検出し, 可視化のための理論構築や技術開発む SPring-8 を中心に行わ れている ${ }^{45)}$ 。動力学回折理論に基づくシュミレーションの結 果と実験結果との対比の重要性も指摘されている。アルミニ ウムのように比較的柔らかく, 低欠陥密度が得られにくい結 晶においても, XT の応用がより容易になることを期待して いる。

筆者の学生時代（1960 年代）には転位論は確立されて日む 浅く, 材料工学（当時は治金学や金属工学）では必ずしも馴 染み深いものではなかったが，筆者には大変新鮮に感じられ たと記憶している。個々の結晶における転位挙動の直接観察 結果と対比することによって理論の検証が行われる一方で, 種々の結晶の転位性状が詳しく調べられ, 新たな発見が次々 となされていた。しかし，転位論と実用材料研究との間には 少し距離があると感じられた。当時 X 線回折顕微法は透過電 子顕微鏡法や転位腐食法などと並ぶ有力な転位の直接観察法 と考えられていた。

半世紀を経た現在, 材料工学の技術者や研究者の間では転 位の存在は至極当然のことであり, 種々の強加工法による材 料の高強度化の例を出すまでもなく, 転位は制御すべき重要 な組織因子となっている。

\section{謝 辞}

このたびは軽金属学会賞をいただき，大変光栄に思います。 これまで有形無形のご指導を賜った多くの先生方や先達に深 甚の謝意を表する次第です。すでに他界された方々には現世 で感謝の意を伝えようもなく，ただ残念でなりません。

学生時代の恩師である九州大学の海江田弘也先生, 北島貞 吉先生, そしてProfessor Jack Washburn (University of California, Berkeley）は浅学非才の筆者を暖かく指導していただき, 研究 の世界へ送り出していただきました。先生方の教えは, 筆者 の研究活動において，随所に生きていることにしばしば気付 かされました。

その後の長い研究生活を通して, 堀内 良先生（東京大 学), 吉永日出男先生 (九州大学) や根本 實先生（九州大 学）をはじめ数多くの方々の指導と激励を受けました。ある ときは直接指導いただき, またあるときは著作に触れて大い に感化され，時には厳しいお叱りのことばや暖かい励ましの ことばをいただきました。Professeur Georges Champier（Ecole des Mines de Nancy）には研究室の一員として公私にわたりお 世話になりました。本稿で述べた X 線回折法に関しては二神 光次先生（九州大学, 宮崎大学), ならびに近浦吉則先生 (九州工業大学, 九州大学) に種々の疑問に答えていただき, また適切な助言をいただきました。

最後に, 単結晶作製, およびX 線回折法や電子顕微鏡法 など忍耐を要する実験を伴う研究に積極的に協力していただ いた共同研究者の方々ならびに学生諸氏に深く感謝致します。

\section{参 考 文 献}

1) A. R. Lang: Modern diffraction and Imaging Techniques in Material Science, eds. by Amelinckx et al., North Holland Pub., (1970), p. 407.

2) B. K. Tanner: X-Ray Diffraction Topography, Pergamon Press, (1976).

3）日本結晶学会誌，特集・X 線トポグラフィ, Vol. 13, No. 6 (1976)。

4）下村保光：X 線材料強度学，養賢堂，(1973), p. 442.

5） 高良和武，菊田惺志：応用物理，36 (1967), 88.

6）美浦康宏：軽金属, 34 (1984), 421-429.

7）古川 稔, 美浦康宏, 海江田弘也：軽金属, 29 (1979), 179185.

8) A. R. Lang: J. Appl. Phys., 29 (1958), 597.

9) W. E. Berg: Naturwiss., 19 (1931), 391.

10) C. B. Barrett: Trans. AIME, 161 (1945), 15.

11) L. G. Schultz: J. Metals, 6 (1954), 1082.

12) F. C. Frank and W. T. Read: Phys. Rev., 79 (1950), 722.

13) J. Bardeen and C. Herring: Imperfections in Nearly Perfect Crystals, Symposium Held at Pocono Manor, 1950., eds. by W. Shockley et al., Wiley, New York, (1952), p. 261.

14) J. Weertman and J. R. Weertman: Elementary Dislocation Theory, Macmillan, New York, (1964).

15）鈴木秀次：転位論入門，アグネ，（1967）。

16) J. P. Hirth and J. Lothe: Theory of Dislocations, Krieger Pub., (1982).

17）美浦康宏：まてりあ， 45-5 (2006), 371, 45-6 (2006), 473.

18) A. R. Lang and G. Meyrick: Philos. Mag., 4 (1959), 878.

19) B. Nost G. Sorensen and E. Nes: J. Crystal Growth, 1 (1967), 149.

20) E. Nes and B. Nost: Philos. Mag., 13-II (1966), 855.

21) C. G'sell, B. Baudelet and G. Champier: J. Crystal Growth, 13/14 (1972), 252

22) Y. Deguchi, N. Kamigaki, K. Kashiwaya and T. Kino: Jpn. J. Appl. Phys., 17 (1978), 611.

23) B. Baudelet and G. Champier: Crystal Lattice Defects, 4 (1973), 95.

24）美浦康宏，古川 稔，藤山謙司，海江田弘也：軽金属， 29 (1979), 451-457.

25）山口和也, 古川 稔, 美浦康宏 : 軽金属学会第 58 回春期大会 講演概要, (1980), 125.

26）紀 隆雄：日本金属学会会報, 23 (1984), 473-478.

27）美浦康宏：日本金属学会九州支部本多記念講演，(2001.10).

28) P. G. Shewmon: Diffusion in Solids, McGraw-Hill, New York, (1963), p. 17.

29）美浦康宏, 古川 稔, 藤山謙司, 海江田弘也：日本金属学会誌, 43 (1979), 1127-1131.

30) J. Friedel: Dislocations, Pergamon Press, (1964), p. 234.

31) R. W. Bailey: J. Inst. Metals, 35 (1926), 27.

32) E. Orowan: Z. Phys., 89 (1934), 614.

33) D. Hardwick, C. M. Sellars and W. J. McG. Tegart: J. Inst. Metals., 90 (1961-62), 21

34）山口和也, 瓜生研一, 美浦康宏 : 軽金属学会第 60 回春期大会 概要, (1981), 11.

35）美浦康宏: 科学研究成果報告（基盤研究 (B), 平成 10 年 3 月).

36) H. Yamagata: Scripta Metall. Mater., 27 (1992), 201-203.

37) H. Yamagata: Scripta Metall. Mater., 27 (1992), 727-732.

38) H. Yamagata: Scripta Metall. Mater., 30 (1994), 411-416.

39) K. Tanaka, M. Otsuka and H. Yamagata: Strength of Materials (Proc. ICSMA10), The Japan Institute of Metals, (1994), p. 787-794.

40）渡辺祥史, 小池俊之, 大塚正久, 山縣 裕：日本金属学会誌, 62 (1998), 44-49.

41）伊原健太郎，美浦康宏：日本金属学会誌，67 (2003), 209-217.

42) F. Haessner and S. Hofmann: Recrystallization of Metallic Materials, ed. by F. Haessner. Dr. Rieder, Verlag, Stuttgart (1978), p. 63.

43）山縣 裕, 大塚正久：まてりあ, 36 (1997), 795-801.

44）戸田裕之, 佐藤眞直, 奥田浩司, 小林正和：軽金属, 61 (2011), 38-48.

45）近浦吉則, 飯田 敏, 川戸清爾, 尾崎 敏, 鈴木芳文: 応用物 理, 71 (2002), 1386-1390. 